ISSN: $2763-5724$

Vol. 01 - n 04 - ano 2021

Editora Acadêmica Periodicojs

\title{
IS COVID-19 PANDEMIC A RISK FACTOR FOR \\ MENTAL DISORDERS IN WOMEN DURING PERI- \\ NATAL PERIOD?
}

\author{
Alan Saiter Luna ${ }^{1}$ \\ Ana Clara Gomes Braga ${ }^{2}$ \\ Christiane Carvalho Ribeiro ${ }^{3}$ \\ Edgard Leandro de Oliveira ${ }^{4}$ \\ Humberto Correa ${ }^{5}$ \\ Kyze Lino Quintela ${ }^{6}$ \\ Lázaro Geraldo dos Santos Xisto ${ }^{7}$ \\ Maria Clara Lemos Oliveira ${ }^{8}$ \\ Victor Araújo Fortuna Cáus ${ }^{9}$
}

1 Universidade Federal de Minas Gerais (UFMG), Belo Horizonte, MG, Brazil

2 Universidade Federal de Minas Gerais (UFMG), Belo Horizonte, MG, Brazil

3 Universidade Federal de Minas Gerais (UFMG), Belo Horizonte, MG, Brazil; Associação Brasileira de Psiquiatria, Belo Horizonte, MG, Brazil

4 Universidade Federal de Minas Gerais (UFMG), Belo Horizonte, MG, Brazil

5 Departamento de Saúde Mental, Universidade Federal de Minas Gerais (UFMG), Belo Horizonte, MG, Brazil. Associação Mineira de Psiquiatria, Belo Horizonte, MG, Brazil

6 Universidade Federal de Minas Gerais (UFMG), Belo Horizonte, MG, Brazil1; Associação Mineira de Psiquiatria, Belo Horizonte, MG, Brazil

7 Universidade Federal de Minas Gerais (UFMG), Belo Horizonte, MG Brazil

8 Centro Universitário de Belo Horizonte (UNIBH), Belo Horizonte, MG, Brazil

9 Universidade Federal de Ouro Preto (UFOP), Ouro Preto, MG, Brazil

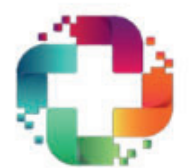


ISSN: 2763-5724

Vol. 01 - n 04 - ano 2021

Editora Acadêmica Periodicojs

Abstract : COVID-19 pande-

mic seems to be associated with increased incidence in mental health disorders in pregnant women. Cross-sectional studies identified control measures, social isolation and recurrent fear of COVID-19 infection may rise risk of depression and suicidality in this specific population. Considering the consequences of the pandemic to health systems, such as saturation and the removal of health professionals, it is crucial to discuss and develop new strategies to maintain antenatal and psychiatric follow-ups to help prevent and treat impairments; teleconsultations may be an alternative to keep contact with these patients. Also, in anticipation of COVID-19 fourth wave (which includes increasing psychiatric disorders) it is important to strengthen mental health services to help absorb this demand.

Keywords: Anxiety; COVID-19; Depression; Mental Health; Perinatal.

\section{Introduction}

New Coronavirus Disease (COVID-19) pandemic, caused by Sars-COV-2, has spread all around the globe and made millions of victims since it has outbreak in November 2019. Sar$\mathrm{s}-\mathrm{COV}-2$ is a novel coronavirus that can be easily transmitted by droplets, personal contact and fômites (World Health Organization, 2020). Due to these characteristics and in order to reduce impacts of the pandemic, most countries around the world adopted quarantine and social distancing measures, which may cause significant impairments in people's mental health, especially in risk groups, such as pregnant 
ISSN: $2763-5724$

Vol. 01 - n 04 - ano 2021

Editora Acadêmica Periodicojs

women (Bedford et al., 2020), s-sectional studies reported hi(Saccone et al., 2020).

In regular circumstances, pregnant women are more vulnerable to some mental disorders, such as depression and anxiety, than non-pregnant women and men (Rennó Jr et al.,2019). (Rondon and Stewart, 2017), (Sikar et al., 2020). The increase of anxiety levels, the greater exposure to domestic violence, burdens related to childcare, domestic and professional activities, financial instability, and fear of being infected by COVID-19 are some issues that could enhance impact in pregnants mental health (Ahorsu et al., 2020), (Sikar et al., 2020).

Quarantine, social distancing, lockdown measures, economic crises, and health system saturation are some of the most challenging components of COVID-19 pandemic. Crosgher levels of depression, suicide behavior and anxiety due to fear, panic, or quarantine and isolation measures adopted worldwide, in pregnant women (Ahorsu et al., 2020), (Saccone et al., 2020). It was also observed that their husbands have being emotionally affected, developing depression and anxiety due to the pandemic impacts, which is related to their partners mental health impairments (Ahorsu et al., 2020).

\section{Discussion}

Brazil figures now as one of the most affected countries. With more than one million of confirmed cases and thousands of deaths, the country has become the epicenter of the pandemic in South America (Latin America Business Stories, 2020). With a 209 million population, $70 \%$ 
exclusively depending on Brazil's health public system (Sistema Único de Saúde - SUS), the country faces a big challenge to deal with COVID-19 pandemic, especially because of the lack of leadership to fight the crisis, and constant measures to reduce SUS funding and the possibility of health system saturation around the country (Mello et al., 2020), (Morosini; 2020), (Silva et al; 2020). Saturated health systems may difficult access to essential care, which significantly increase morbimortality from preventable and treatable conditions, (Silva et al; 2020). Also, the removal of health professionals, either because they belong to risk groups or because of illness due to $\mathrm{CO}$ VID-19, and some negationism of the pandemic may contribute to spread it. In order to help stop spreading the decease, it is extremely important that people can access information from reliable sources and misinfodemic must be opposed (Banerjee, 2020), (Silva et al; 2020), (Helioterio et al., 2020).

As an alert to prevent negative outcomes, World Health Organization (WHO) recommends that antenatal care and mental health services must be maintained and adapted to the pandemic context, including telemedicine for follow-up, visits, and mutual-help groups (World Health Organization, 2020). Some studies defend that internet-based intervention focusing on relaxation, self-care and an increased sense of security for patients with COVID-19, are positive measures to minimize psychological distress, improving mental health in cases of depression and anxiety (Vieira et al; 2020), (Wei et al; 2020).

In times of great ten-

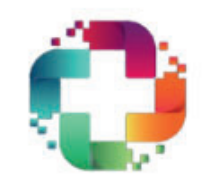


Vol. 01 - n 04 - ano 2021

Editora Acadêmica Periodicojs

sion and insecurity with the COVID-19 pandemic, mental health is an issue that deserves even more attention and alert in this period. In order to help prevent mental health impairments, health professionals may develop strategies for education about expected psychological changes and how to deal with them and the excess of misinformations about the pandemic, encouragement of self-care, health-promoting behaviors and empowerment of patients and Family (Silva et al; 2020), (Vieira et al; 2020).

Depreciation of mental health system has extremely dangerous consequences for population. As an example, Hospital Galba Velloso, in Belo Horizonte, Brazil, had its psychiatric ward completely closed, which may lead to a chaotic scenario, once it was one of the most important reference in psychiatric emergency in the city. During the pandemic and facing the increase of mental health issues, non-investing in psychiatric services is a reckless decision (Correa et al; 2020), (Ministério Público de Minas Gerais, 2020).

Anticipating the impacts of COVID-19 on mental health ("fourth wave") and the expectation of an increase in psychiatric urgencies and emergencies, there is a mobilization to prevent the shutdown of psychiatric beds at Hospital Galba Velloso; Minas Gerais Public Prosecutor's Office filed a lawsuit to reestablish the functioning of these beds and avoid the deterioration of the State's Psychosocial Care Network, especially in a critic period of pandemic (Ministério Público de Minas Gerais, 2020). According to Correa (Correa et al; 2020), the role of a psychiatric hospital permeates social actions and specific

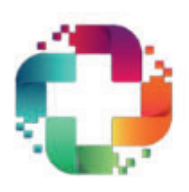


cares for contagion prevention, since patients in crisis may not be able to understand importance of hygiene measures, nor isolation need which may eventually require specialized hospitalization.

In special attention to pregnant women mental health, it is important to highlight the need to maintain antenatal appointments to ensure a safer evolution of the mother-baby binomial, during pregnancy. Aware of the vulnerability of pregnant women to the incidence of mental disorders, such as depression and anxiety, and the increased risk associated with COVID-19, World Health Organization suggests special attention to these women and proposes the development of new strategies to guarantee health care, respecting social distancing and hygiene measures to avoid COVID-19. The organization encourages teleconsul- tations, internet-based strategies to help cope with distress, isolations and anxiety, access to reliable information on the pandemic and avoid misinfodemia exposure (World Health Organization, 2020). Also, it is crucial to guarantee that pregnant women dealing with a mental disorder have all access to their treatments and follow-ups, to avoid relapses and more crisis.

\section{Conclusion}

The unique scenario that COVID-19 pandemic is providing demands self-criticism and innovation actions to minimize damages in all sectors of society. In addition to outpatient and hospital care, researches also face difficulties in maintaining its activities. With the suspension of most activities taking place at the State University of Minas Gerais,

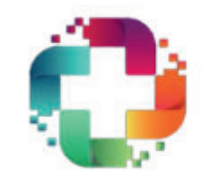


Vol. 01 - n 04 - ano 2021

Editora Acadêmica Periodicojs

researches on mental health in the perinatal period is suspended until further recommendation or restructuring to guarantee volunteers safety. Far beyond $\mathrm{CO}$ VID-19, other diseases continue to affect population and require attention for prevention and caring. It is necessary to encourage the debate on the development of a global strategy for coping with health crises and the definition of what in fact is essential and must not be contingent in a scenario like the current. More than ever, the pandemic has highlighted the importance of investments on public health, science and technology, which are much underfunded and depreciated in Brazil.

\section{Bibliographical references}

Ahorsu, Daniel Kwasi et al., (2020). Associations Between Fear of COVID-19, Mental He- alth, and Preventive Behaviours Across Pregnant Women and Husbands: An Actor-Partner Interdependence Modelling. International Journal of Mental Health and Addiction.

Banerjee, Debanjan; (2020). The COVID-19 outbreak: Crucial role the psychiatrists can play. Asian J psychiatry. 50:102014.

Bedford, Juliet et al., (2020). COVID19: towards controlling of a pandemic. Lancet. 395:1015-8

Correa et al; (2020). Why psychiatric treatment must not be neglected during the COVID-19 pandemic. Braz J Psychiatry.

Helioterio, Margarete Costa et al; (2020). COVID-19: por que a proteção da saúde dos trabalhadores e trabalhadoras da saúde é prioritária no combate à pande- 
mia?.

Latin America Business Stories:

Paraná: Sociedade [Internet].

2020 may 18 [cited 2020 jun28].

https://labs.ebanx.com/en/news/ society/south-america-has-become-the-newepicenter-of-covid-19/

Mello, Guilherme et al., (2020). A Coronacrise: natureza, impactos e medidas de enfrentamento no Brasil e no mundo. Campinas: Cecon, IE/UNICAMP [Internet]. 19 de março 2020 [cited Jun 30 2020]. http://www3.eco.unicamp. br/images/arquivos/nota_cecon_coronacrise_natureza_ impactos_e_medidas_de_enfrentamento.pdf

Morosini, Liseane; (2020). Saúde estrangulada: chegada do novo coronavírus ocorre no contexto em que a atenção básica pas- sa por mudanças em seu perfil

e sofre com perdas de recursos.

RADIS: Comunicação e Saúde.

213:28-31.

Ministério Público de Minas Gerais: Superintendência de Comunicação Integrada; Diretoria de Imprensa. Belo Horizonte [Internet]. 31 de março 2020 [cited 2020 Jun 28]. https://www.mpmg. mp.br/comunicacao/noticias/ em-meio-a-pandemia-do-covid-19mpmg-requer-a-justica-que-estado-e-fhemig-restabelecam-o-atendimento-psiquiatricono-hospital-galba-velloso-em-bh. htm

Rennó Jr., Joel et al., (2019). Women's Mental Health: A Clinical and Evidence-based Guide. Springer Nature.

Rondon, Marta and Stewart, Donna (2017). Disentangling the 
heterogeneity of perinatal de- vida não escolhe tempo para naspression. The Lancet. Psychiatry. cer (VIDA): Recomendações do 4:432-433.

Grupo de Língua Portuguesa da

Sociedade Marcé Internacional

Saccone, Gabriele et al., (2020) para a Saúde Mental Perinatal.

Psychological impact of corona- The Marcé Society for Perinatal virus disease 2019 in pregnant Mental Health.

women. Am J Obstet Gynecol.

Wei et al; (2020). Efficacy of in-

Sikar, Karen et al., (2020). Peternet-based integrated intervenrinatal mental health during the tion on depression and anxiety COVID-19 pandemic. Women and Birth. 33:4-309.

symptoms in patients with $\mathrm{CO}$ VID-19. J Zhejiang Univ Sci B. $21 ; 400-440$.

Silva et al; (2020). Covid-19 in Brazil has exposed socioeconoWorld Health Organization mic inequalities and underfun(WHO). Coronavirus disease ding of its public health system. The BMJ. 2019. Situation Report [Internet]. 17 April 2020 [cited 2020

Jun 30]. https://www.who.int/

Silva et al; (2020). Mental health: docs/default-source/coronaviruwhy it still matters in the midst se/situation-reports/20200417-siof a pandemic. Braz J Psychiatry. 42:229-231. trep-88-covid-191b6cccd94f8b4f219377bff55719a6ed. pdf?sfvrsn=ebe78315_6

Vieira et al; (2020). Quando a 
Vol. 01 - n 04 - ano 2021

Editora Acadêmica Periodicojs

World Health Organization.

Mental health and psychosocial

considerations during the CO-

VID-19 outbreak [Internet]. 18

March 2020 [cited 2020 jun 30].

https://www.who.int/docs/defaul-

t-source/coronaviruse/mental-he-

althconsiderations.pdf?sfvrsn=-

6d3578af_2 